\title{
RATS AND THE MONGOOSE IN JAMAICA
}

\author{
By C. B. Lewis
}

The European brown and black rats probably reached Jamaica by the earliest ships. In any case these prolific rodents, along with the equally prolific cane-piece rat, have always been a tremendous problem on sugar estates, and for several hundred years estate owners have found it necessary to expend large sums for rat catching.

In 1762 Thomas Raffle introduced from Cuba the ant (Formica omnivora), which has since been known as "Tom Raffle" ant, to prey upon young rats. These ants are said to have been very useful for many years, but gradually they either decreased in effectiveness or became reduced in numbers. In any case they became a pest themselves. The "bull frog" (Bufo marinus) was introduced by Mr. Anthony Davis in $\mathbf{1 8 4 4}$ also to destroy the young rats. It is not known whether the " bull frog", which is really a toad, was ever even locally effective in this respect, in any case the rats were as abundant as ever.

By 1870 approximately one-fifth of the produce of a large sugar estate was lost, while rat-catching cost that estate over $£ 200$ per annum. (As many as 20,000 rats were destroyed annually by rat catchers at the rate of $1 d$. per head on one estate in Trelawny.) The wet districts, St. Thomas, Portland and Westmoreland, suffered most severely, and it is reported that some estates in the Swift River valley were actually abandoned because of the rats. The total loss by rats to Jamaica was estimated at not less than $£ 100,000$ per annum.

An attempt was made to introduce the European ferret but this met with failure, as the ferret could not overcome the attacks of chiggers. In 1816, in Hortus Jamaicensis, Lunan suggested the introduction of the mongoose from India. The mongoose, being an animal with a natural antipathy to rats, might probably, to quote Lunan, " extirpate the whole race of the vermin." Around $\mathbf{1 8 7 2}$ many animals were imported by a number of different estates, but all of these animals were obtained from London, having been bred in captivity. They proved to be useless when it came to catching rats, for, as one estate owner put it, "they were literally afraid of a rat." Mr. W. B. Espeut, of Spring Garden Estate, Portland, was the first to import some animals direct from India. Probably all of the animals on the island to-day are descendants of the four males and five females which he liberated on his estate in $\mathbf{1 8 7 2}$. 
The mongoose, a member of the civet-cat family, took to its task of rat destruction, and reduced the expense of rat-catching tremendously. In some areas abandoned land was taken up again three years after the introduction of the mongoose. Ten years after the first introduction to the island it was estimated that the mongoose was saving the island approximately $\mathfrak{\$ 4 5 , 0 0 0}$ annually.

Mr. D. Morris, Director of Public Gardens and Plantations in Jamaica, writing in 1882, suggested the problem of the future when he said : "The introduction and complete naturalization of an animal possessing such strong predatory habits and remarkable powers of reproduction, must have an important influence on all indigenous and introduced animals capable of being affected by it." The natural food of the mongoose is birds, snakes, lizards, rats, mice and, last but not least, the eggs of both birds and reptiles. The depredations of these animals on poultry and other domestic animals were soon noticed, particularly by the peasantry. By 1882 scientists noticed the rapid diminishing of ground nesting birds, sea and water fowl, the yellow snake, which was itself a good rat catcher, and ground lizards.

By 1882 the mongoose had spread to all parts of the island, and by 1890 a Commission was set up by the Governor to inquire into and report on the question whether it was expedient that measures should be taken to reduce the number of mongoose. Some members of this commission reported, only eighteen years after the initial introduction, that the benefit which a particular class had received had been more than counterbalanced by the serious injury to the island in general. The chief sufferers, next to the native wild life itself, being the small proprietors and the peasantry.

While the mongoose had greatly lessened the number of rats in the cane fields and in the cocoa walks and coffee plantations, where previously the rat damage had been estimated at $£ 15,000$ per annum, many rats had taken refuge in coconut trees. Rats generally, and especially the black rat which nests in trees and is a splendid climber, had become arboreal where they were comparatively safe from the mongoose. The mongoose was soon to adapt itself, and was taking to low branching trees by 1882 . It was also becoming omnivorous, taking fruits of all kinds, fish and young coney.

The native iguana was soon made extinct on the southern slopes of Jamaica leaving a remnant colony of the species on the Goat Islands. The extinction of the iguana is now being com- 
pleted by the mongoose which reached the Goat Islands a decade or so ago. The blame for the great decrease in the number of land crabs has also been placed on the small shoulders of the mongoose.

The introduction of any animal into a new habitat involves certain important and highly complicated biological principles and interrelationships. In any long established, undisturbed area the native plants and animals exist in fairly constant proportions - a natural balanced condition. The balance of populations fluctuate slightly from year to year and may, over a period of years, gradually change; but if a highly prolific predatory animal is introduced into a community, which will provide no natural enemies, it is obvious that the natural balance of the community will be greatly upset.

The unfortunate introduction of the mongoose into West Indian islands is cited the world round, and will continue to be cited as an example of ill-advised tampering with established natural conditions. The mongoose was introduced without consideration of its habits, other than its antipathy to rats. Eventually the mongoose will assume its place in a new balance of the wild life community, but in the meantime certain species of animals will have become extinct and many others will have become reduced in numbers and changed in habits.

Unfortunately there have been no regular wild life surveys which would give us reliable comparative information on the position of the mongoose in the island wild life community. The report of the 1890 Commission and subsequent reports have depended considerably upon the statements made by planters and not upon scientific investigation. Jamaica must accept the mongoose as a permanent resident for it is too late to think of its elimination. The depredation by the mongoose will serve as a constant reminder of the importance of understanding wild life and its problems. Think twice before upsetting Nature's balance!

The above article is reprinted with permission from Glimpses of Jamaican Natural History, vol. i. 